\title{
NSF does well, NIH does not in Clinton's 1994 budget
}

Washington. The US budget for fiscal year 1994 that President Bill Clinton will next week send to Congress assigns a favoured position to the US National Science Foundation (NSF) in the projected economic recovery while treating the US National Institutes of Health (NIH) as a bit player, reinforcing the perception that the president's vision for technological change does not include biomedical research.

The president is requesting $\$ 216$ million more in the year beginning on 1 October for NSF, an increase of 7.3 per cent that would raise its budget to $\$ 3.18$ billion. This week the US Congress was expected to approve a \$16-billion supplementary budget package for 1993 that would add $\$ 206$ million to NSF's existing budget. Even so, a combination of those two increases would raise NSF only slightly above the level requested last year by former President George Bush but rejected by the US Congress.

In contrast, unofficial budget figures for NIH show an increase of only 3.3 per cent ( $\$ 340$ million) that would bring its budget to $\$ 10.67$ million. The increases are almost entirely in three areas - breast cancer research, AIDS and the human genome project - previously targeted for growth by the Congress and the administration, leaving nine of the 18 institutes and centres with less money next year than at present.

This has been an unusual year for the president's budget, normally submitted to Congress at the end of January. New rules allowed Bush to compile only an outline of the annual $\$ 1,500$ billion federal budget; despite working feverishly for several weeks, the new administration has pushed back from mid-March to early April the release of its budget. Congress has begun work on the budget anyway, with NSF and NIH officials testifying last week at separate appropriations hearings. NSF provided details the next day, but $\mathrm{NIH}$ is officially remaining silent until the full budget is unveiled sometime next week.

For NSF, the good news in the president's request is an increase of 7 per cent for its basic research programmes, 14 per cent more for science and mathematics education and enough to keep three major new facilities on schedule - $\$ 17$ million towards twin 8-metre telescopes to be built jointly with Britain, Canada and three Latin American countries, $\$ 43$ million towards a laser interferometer gravity wave observatory (LIGO) and \$12 million towards a national high magnetic field magnet laboratory. The bad news is that Congress, which jealously guards its role in setting spending priorities, may remember NSF's good fortune this year in getting a supplementary budget that provides about half of the increase it had originally sought from Congress.

"If this committee had had an additional $\$ 206$ million available to it last year, it probably would not have given it all to the NSF", said Representative Louis Stokes (Democrat, Ohio), chairman of the House appropriations subcommittee that funds NSF and several other agencies. "And if this subcommittee's allocation does not match the president's 1994 request, we'll have to take into account the rather generous increase given to NSF in the 1993 supplemental."

In contrast, there is little for $\mathrm{NIH}$ to cheer about in what Clinton has so far proposed. The supplementary appropriation contains only $\$ 9$ million for its share in a high-speed computer initiative, and the 1994 request, if

\section{NIH plans to begin AIDS drug trials at earlier stage}

Washington. The US National Institutes of Health (NIH) will begin treating people who are HIV-positive as soon as possible after infection in the wake of new information (see Nature 362, 355; 1993) that the HIV virus is active in the body in large numbers much earlier than was previously thought.

"We must address the question of how to treat people as early as we possibly can with drugs that are safe enough to give people for years and that will get around microbial resistance", says Anthony Fauci, director of the US National Institute of Allergy and Infectious Diseases (NIAID). Any delay, he adds, would be the result of questions regarding safety and resistance rather than a lack of funds.

However Fauci, who co-authored one of the two papers on the subject published last week (Nature 362, 355 \& 359; 1993), hotly denies the suggestion by one of his co-authors, Cecil Fox, that the new evidence means that " $\$ 1$ billion spent on vaccine trials" has been "a waste of time and money" because the trials were started too long after the patients were infected and were ended too quickly. Fox, of the Yale University School of Medicine, says that data showing the extent to which the HIV-1 virus is active in the lymphoid organs during the early stages of HIV infection mean that "for the first time, the pathogenetic dynamics of the disease are

properly understood".

But Howard Temin of the University of Wisconsin is more cautious. "I only wish life were so simple", he says. "If we understood its pathogenesis we'd understand how the HIV virus does what it does - but that mystery has not dissipated."
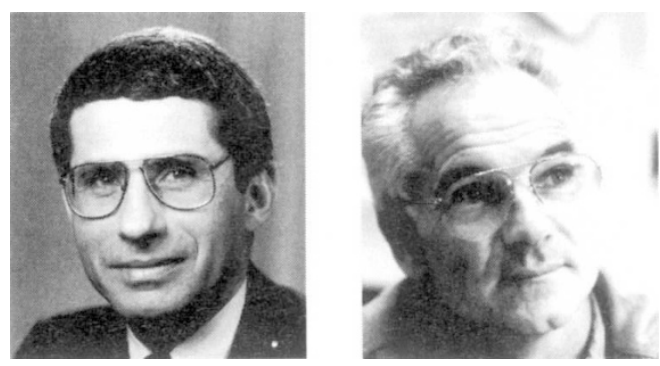

No meeting of minds for Fauci, left, and Duesberg.

John Tew of the Medical College of Virginia in Richmond says that the new evidence makes a strong case for early treatment of HIV-positive patients. "These data would argue that early intervention is critical and, if they are correct, that very early intervention may have a heck of a lot of benefits."

AIDS activists welcomed the new information but said that the scientific community has been slow to understand the significance of infection of the lymph tissue.
"We've known about this for five years, but we're glad it is now in the public domain", says Jesse Dobson of the California-based Project Inform. Dobson says that he hopes the work would lead researchers to take "a more pathogenesis-focused approach, as opposed to a drugs-based approach".

The authors of the papers and their supporters see the evidence of infected lymphoid tissue as a mixed blessing in treating HIV-positive patients before AIDS develops. As Ashley Haase of the University of Minnesota and co-author of one paper, puts it: "It is very sobering that we have infection early on, on such a vast scale. But I'm impressed by how the human immune system is able to contain the infection for a very long time."

Critics of the conventional view of HIV as the precursor of AIDS say that there is nothing in the papers to change their minds. Peter Duesberg of the University of California at Berkeley says that the data are "absolutely irrelevant" to AIDS. "We are several paradoxes away from an explanation of AIDS - even if these papers are right", says Duesberg, who believes that AIDS is independent of HIV and is a result of recreational drug abuse in the West and immunization programmes in the developing world.

Colin Macilwain 